of the politics of education. It can be strongly recommended to both because it is soundly based on a careful scrutiny and scholarly evaluation of documents and an exhaustive enquiry; above all, it is written by an "insider" (the author's own term). This last point is of special importance for although there are many pieces, published and unpublished, which are written about higher education in Britain few of the authors have Sir Peter Venables' very wide experience. These writers fall into a very wide range. Thus at one extreme the authors are lonely scholars, either MA or PhD thesis writers or their own senior colleagues, more often than not embedded in a School of Education, itself on the fringe rather than in the mainstream of the activities of its parent institution. Such authors' sources are restricted to public documents and their experience is unlikely to embrace that of treading the corridors of a local education authority, the Department of Education and Science, the Scottish Education Department, the Welsh Office or even the UGC. The fruits of their labours are, however, likely to be published perhaps in book form or as articles in journals for all to see, dissect and evaluate. At the other extreme there are the civil servants whose duties are to prepare influential position (and policy) papers which rarely ever find their way into the open literature - at least legitimately. Their own direct experience of higher education is likely to have been limited to a few years at a university ten, twenty or even thirty years earlier. So the scholar suffers from ignorance of the "real", as distinct from the "openly acknowledged", political and intellectual reasons for decisions; and the civil servant who is well placed to influence those decisions has no living, working contact with the "coal-face" of higher education.

This gap is deplorable, as it is likely to militate against the formulation of the most beneficial policies. How is it to be bridged? The Royal Commission is one device. It is certainly open and thorough but also often cumbrous and slow; and it is not a permanent bridge. There are a few helpful signs in, for example, what seems to be a greater willingness and/or freedom of the public servant to discuss issues with scholars and researchers and the welcome tendency to issue "Discussion Documents" and "Green Papers" before decisions are taken. Then there is the occasional forum or symposium which is, however, rarely productive of meaningful interaction between the civil servant who, restrained by the rules and conventions of his employment, may elect to stay silent at a public gathering on just those topics which, being of greatest contemporary interest and importance, are therefore also the most sensitive issue.

The situation would be much improved if there were some exchange of people between posts in Academe and the Public Service. But mobility, though repeatedly

advocated as desirable, remains and is likely to remain far too infrequent. In our British system the best we can hope for is the lucky chance either that academics and ex-civil servants are able to collaborate (as in the case of Becher, Embling and Kogan's brief study of higher education) or that some able person who has been deeply involved as a teacher and administrator in higher education institutions for most of his life, helping to shape them during a period of rapid development, who has also served on many national bodies in ways which have brought him into close contact with civil servants, local authority officials and politicians, will make time to take stock of the past and present and point out the options for the future.

Such a man is Sir Peter Venables. His career in higher education, especially in technological universities and their precursors, will be known to many as

\section{Energy melting pot}

\section{Peter Rost}

Energy and the Environment: Democratic Decision-Making. Edited by C. Lenzer, C. Phipps, J: Valleix and J. Surrey. Pp. 141. (Macmillan: London, 1978.) $£ 5.95$

IT was not until the oil crisis of 1973-74 that politicians woke up to realise that they now had to face yet another challenge. Until then the provision of energy at an acceptable price was taken for granted. Energy policy was regarded as the preserve of technical experts and the balance between supply and demand was satisfied by the market. Now energy has become a dominant world political problem.

The energy debate has not lacked documentation. Students anxious to be alarmed or reassured about the prospects for mankind's future energy resources have been deluged with reading material. But each such contribution to the argument has been a personal interpretation, or a consensus by an expert group. What has been less readily presented to the informed but enquiring reader, is an actual crosssection of the debate itself.

This is why this book is an important contribution to the evolving energy debate. It records a two-day colloquy organised in November 1977 by the Council of Europe, which brought together 70 politicians from Europe and North America, with an equal number of independent experts. The Parliamentarians represented a formid- qualifying him well for this task, to which he has also brought the scientist's insatiable appetite for facts and a method of enquiry borrowed from the woman who is both his sociology instructor and wife. The result is predictable and well worth the effort. I have only two regrets. The style is almost too 'dead pan', too detached and at a number of places I would have liked Sir Peter to be a little more 'unbuttoned' and to have given us the benefit of his own opinions even when they could not be completely buttressed by evidence. His own long and devoted service to the cause of technological education have earned him that right. My second regret is that the price should be so exorbitant and therefore the book may not get the circulation is deserves.

Sir Frederick Dainton was, until 30 September 1978, Chairman of the University Grants Committee, London, UK.

able array of spokesmen many of whom have established their national and international political reputations for their specialist contributions to energy studies, whereas the technical and industrial experts included many reputable figures from international organisations concerned with energy problems, of high standing in scientific, academic and international circles.

Such a rich mixture into a two-day melting pot could easily have created an indigestible meal, But the themes were well defined and the debate was disciplined. Four principle aspects were tackled-energy supply and demand to the year 2000; the contribution of fossil fuels and renewable sources; the nuclear debate; and options for the future.

Perhaps surprisingly, some consensus emerged. No one energy source will solve the future, real costs will rise and conservation must move up the league table of priority options.

Revealing too, is the admission by decision takers, that they (the decision takers) will have to face up to unpopular measures! Long term policies to provide enough energy, yet protect the environment, maintain living standards and preserve democracy, may require electorally unpopular choices.

This book should help to reassure the informed public that, although the experts will never agree any more than politicians, at least the debate is being carried forward on solid intelligent foundations of scientific knowledge and political maturity. We must hope that Parliamentarians will follow up with the correct policy decisions.

Peter Rost is Member of Parliament for South-East Derbyshire, a Member of the Select Committee on Science and Technology Sub-Committee on Energy $R e$ sources, and Member of the Conservative Parliamentary Energy Group. 